\title{
Picogram per Hour
}

National Cancer Institute

\section{Source}

National Cancer Institute. Picogram per Hour. NCI Thesaurus. Code C85779.

Picograms per hour. 